\title{
PENGELOLAAN MODEL PENDIDIKAN TEMAN SEBAYA (PEER GROUP) DALAM PENCEGAHAN PENYALAHGUNAAN NARKOBA
}

\author{
Vita Camellia'), Tuti Atika ${ }^{2)}$ \\ ${ }^{1)}$ Staf pengajar Prodi Kedokteran Umum FK USU \\ Email: camelliavita@yahoo.com \\ ${ }^{2}$ Staf pengajar Prodi Kessos FISIP USU \\ Email: tutiatika91@yahoo.co.id
}

\begin{abstract}
ABSTRAK
Kampung Kubur berada di Jl. Zainul Arifin, Lingkungan I Kelurahan Petisah Tengah Kecamatan Medan Petisah Kota Medan. Jumlah masyarakat Kampung Kubur terdiri dari 270 kk, 1093 jiwa. Identik dengan peredaran narkoba telah membuat stigma negatif bagi warga. Awal tahun 2015 peredaran narkoba di Kampung Kubur menjadi sorotan perhatian masyarakat Indonesia. Penggerebekan dadakan sering dilakukan dengan tujuan agar Kampung Kubur terbebas dari pengaruh negatif peredaran narkoba. Permasalahan baru kemudian muncul seiring semakin hilangnya peredaran narkoba dari daerah tersebut. Banyak masyarakat yang kehilangan sumber mata pencahariannya. Kelompok remaja juga menjadi resah. Geliat ekonomi berkurang drastis. Bermain keluar Kampung Kubur untuk mengisi waktu luangnya juga ragu tidak diterima, karena stigma negatif yang melekat. Dalam mekanisme terjadinya penyalahgunaan zat, teman kelompok sebaya (peer group) mempunyai pengaruh yang dapat mendorong atau mencetuskan penyalahgunaan narkoba pada diri seseorang. Teman sebaya memiliki pengaruh terhadap perilaku konsumsi zat-zat seperti tembakau, alkohol, dan obat-obatan lainnya. Teman sebaya merupakan faktor eksternal yang juga dapat memengaruhi pergaulan pada remaja, baik itu pergaulan yang positif maupun pergaulan yang negative. Pengabdian ini dilaksanakan di Kampung Kubur. Target luaran dari pengabdian ini adalah mitra memahami arti penting hidup sehat tanpa narkoba, mampu membangun kembali rasa percaya dirinya, mampu mengelola usaha doorsmeer, terbangunnya usaha doorsmeer yang menjadi pengisi waktu lenggang dan sumber pendapatan baru bagi mitra karena mendatangkan nilai ekonomi.
\end{abstract}

Kata kunci : Narkoba, Remaja, Teman Sebaya, Usaha Doorsmeer

\section{PENDAhuluan}

Kampung Kubur berada di Jl. Zainul Arifin, Lingkungan I Kelurahan Petisah Tengah Kecamatan Medan Petisah Kota Medan. Jumlah masyarakat Kampung Kubur terdiri dari 270 kk, 1093 jiwa. Kampung Kubur sejak tahun 1970-an sudah menjadi sarang peredaran narkoba di Kota Medan. Lebih 40 tahun sebagian masyarakat Kampung Kubur telah menikmati 'hasil' peredaran narkoba.

Identik dengan peredaran narkoba telah membuat stigma negatif bagi warga. Sebagian dari mereka merasa kesulitan mencari pekerjaan di luar Kampung Kubur. Dengan menyatakan sebagai warga Kampung Kubur mereka sering mendapat penolakan untuk bekerja di luar wilayahnya.
Awal tahun 2015 peredaran narkoba di Kampung Kubur menjadi sorotan perhatian masyarakat Indonesia. Ini mengakibatkan semakin intensnya perhatian semua pihak khususnya aparat kepolisian dan BNNP Sumatera Utara. Penggerebekan dadakan sering dilakukan dengan tujuan agar Kampung Kubur terbebas dari pengaruh negatif peredaran narkoba.

Permasalahan baru kemudian muncul seiring semakin hilangnya peredaran narkoba dari daerah tersebut. Banyak masyarakat yang kehilangan sumber mata pencahariannya. Kelompok remaja juga menjadi resah. Geliat ekonomi berkurang drastis. Bermain keluar Kampung Kubur untuk mengisi waktu luangnya juga ragu 
tidak diterima, karena stigma negatif yang melekat.

Untuk itu guna mencegah kelompok remaja ini masuk kembali dalam peredaran negatif narkoba maka perlu untuk mengisi waktu mereka dengan hal-hal yang positif dan bermanfaat. Teman sebaya mempunyai pengaruh besar bagi anak-anak remaja, mereka merasa dekat satu sama lain dan biasanya sudah membentuk kelompok (geng), mereka mempunyai rasa senasib dan sepenanggungan, rasa solidaritas tiggi. Dengan demikian, mereka akan dengan mudahnya melakukan hal-hal yang dianggap menyenangkan oleh kelompoknya. Mereka tidak memikirkan baik buruknya, tetapi memikirkan apa itu menyenangkan atau tidak. Juga tidak mempertimbangkan akan adanya resikoresiko bagi dirinya. Bahkan, untuk memenuhi keinginannya agar diterima kelompoknya, mereka tidak segan-segan melakukan hal-hal yang sebenarnya disadari merupakan perbuatan yang tidak baik.

Hawari dalam penelitiannya menyebutkan bahwa $81,3 \%$ seseorang yang menggunakan narkoba diawali oleh pengaruh/bujukan teman (peer group). Penolakan atau tekanan dari kelompok/ teman sebaya mengakibatkan remaja merasa dikucilkan, oleh karena itu tidak mudah bagi remaja untuk meninggalkan kelompok. Meninggalkan kelompok bagi remaja berarti kehilangan teman serta sebagian hidupnya (Sally, 2012).

Dalam mekanisme terjadinya penyalahgunaan zat, teman kelompok sebaya (peer group) mempunyai pengaruh yang dapat mendorong atau mencetuskan penyalahgunaan narkoba pada diri seseorang. Pada banyak kasus, perkenalan pertama dengan narkoba biasanya datang dari teman sebaya.

Teman sebaya memiliki pengaruh terhadap perilaku konsumsi zat-zat seperti tembakau, alkohol, dan obat-obatan lainnya. Teman sebaya merupakan faktor eksternal yang juga dapat memengaruhi pergaulan pada remaja, baik itu pergaulan yang positif maupun pergaulan yang negative. Pergaulan positif seperti kelompok belajar, dan keikutsertaan dalam kegiatan ekstrakurikuler yang bermanfaat. Sedangkan pergaulan negatif adalah yang berhubungan dengan kenakalan remaja, seperti pengkonsumsian narkotika, alkohol, psikotropika, dan zat adiktif (napza) yang pada saat ini sudah banyak.

Melihat analisis situasi tersebut membuat tim pengusul merasa perlu unutk melakukan pengabdian pada masyarakat ini dengan judul "Pengelolaan Model Pendidikan Teman Sebaya (Peer Group) Dalam Pencegahan Penyalahgunaan Narkoba".

\section{PERMASALAHAN MITRA}

a. Rendahnya pengetahuan kelompok mitra mengenai arti penting hidup sehat tanpa narkoba.

b. Rendahnya rasa percaya diri kelompok mitra karena stigma negatif yang sudah melekat.

c. Rendahnya pengetahuan dan keterampilan kelompok mitra dalam cara mengelola dan mengembangkan usaha doorsmeer.

d. Minimnya modal usaha kelompok mitra untuk dapat membangun dan menjalankan usaha doorsmeer sebagai upaya mengisi waktu luang sekaligus memperoleh pendapatan.

e. Rendahnya pengetahuan kelompok mitra dalam pengelolaan usaha doorsmeer yang profesional dan memberikan kepuasan kepada pelanggan untuk mendatangkan keuntungan ekonomi, sehingga mampu meningkatkan pendapatan secara signifikan.

\subsection{Solusi Yang Ditawarkan}

1. Diskusi, menjelaskan dan meyakinkan mitra tentang pentingnya hidup sehat tanpa narkoba. 
2. Melaksanakan penyuluhan untuk membangkitkan rasa percaya diri mitra.

3. Melaksanakan pelatihan cara mengelola doorsmeer dan membangun kepercayaan pelanggan.

4. Membimbing mitra menjalankan manajemen usaha doorsmeer sehingga mampu menghitung laba dan menganalisis biaya yang baik, yang bermuara pada peningkatan pendapatan.

5. Membangun usaha doorsmeer.

\subsection{Target Luaran}

1. Mitra memahami arti penting hidup sehat tanpa narkoba.

2. Mitra mampu membangun kembali rasa percaya dirinya.

3. Mitra mampu mengelola usaha doorsmeer dan membangun kepercayaan pelanggan.

4. Terbangunnya usaha doorsmeer dan terciptanya wirausahawan doorsmeer.

5. Menjadi pengisi waktu lenggang dan sumber pendapatan baru bagi mitra karena mendatangkan nilai ekonomi.

\section{METODE PELAKSANAAN}

\subsection{Rencana Kegiatan}

1. Diskusi

Dilakukan oleh tim pengabdian tentang rencana kegiatan. Berdasarkan diskusi ini tim pengabdian akan dapat mengetahui ketertarikan masyarakat terhadap kegiatan pengabdian. Selain itu dapat membangun motivasi tinggi untuk meningkatkan keterampilan usaha.

2. Penyuluhan

Dilakukan oleh tim pengusul untuk menjelaskan pentingnya hidup sehat tanpa narkoba. Tanpa narkoba, rasa percaya diri dan optimisme untuk menjalani hidup lebih baik akan terbangun.

3. Pelatihan dan pembangunan usaha doorsmeer
Pelatihan dimulai dengan pembangunan usaha doorsmeer. Hal ini dilakukan karena diyakini bahwa pelatihan usaha doorsmeer akan lebih efektif jika disertai dengan membangun fasilitas yang dibutuhkan dalam usaha doorsmeer. Pelatihan dilakukan dengan mengundang pakar yang memang sudah berpengalaman dalam membuat dan menjalankan usaha doorsmeer. Dalam pelatihan ini maka tim pengabdian akan memfasillitasi dan menyediakan semua bahan-bahan dan peralatan yang diperlukan dalam usaha doorsmeer.

4. Bimbingan

Dalam pelatihan ini tim pengabdian akan mengajarkan bagaimana cara membangun kepercayaan pelanggan. Selain itu juga memberi pelatihan agar memiliki mental kewirausahaan serta mampu dan percaya diri dalam mengembangkan usaha doorsmeer.

5. Evaluasi

Evaluasi akan dilakukan selama pelaksanaan kegiatan pengabdian yang meliputi pengamatan keterampilan dalam usaha doorsmeer dan pengamatan dalam strategi pemasaran. Selain itu juga evaluasi akan dilakukan meskipun kegiatan pelatihan sudah selesai, yaitu dengan bertelepon menanyakan komitmen hidup sehat tanpa narkoba, kemajuan usaha doorsmeer selama ini dan juga dengan mengunjungi kembali serta menanyakan hambatan dan keuntungan yang dijumpai setelah kegiatan pelatihan selesai dilakukan.

\subsection{Kontribusi Partisipasi Mitra}

1. Mitra bersedia mengikuti segala bentuk penyuluhan dan pelatihan. Berniat untuk merubah pola hidup menjadi lebih sehat.

2. Mitra akan diminta supaya berkomitmen menghindari peredaran negatif dan penyalahgunaan narkoba. 
3. Mitra akan diminta supaya aktif dan berkomitmen untuk menjalankan usaha doorsmeer sesuai dengan yang dianjurkan.

4. Mitra bersedia mengikuti pelatihan strategi dalam pemasaran yang akan dipraktekkan oleh mitra untuk menjamin keberhasilan usaha mereka. Mitra bersedia menerapkan apa yang telah diajarkan pada pelatihan dan bersedia dievaluasi.

5. Mitra bersedia juga mengikuti pelatihan dalam menghitung total pendapatan, mengetahui faktor-faktor yang menentukan besarnya pendapatan penjualan. Mitra mampu menghitung total biaya dan mengetahui cara untuk meminimalkan biaya produksi serta mampu menghitung keuntungan per bulan.

6. Mitra bersedia dan diteguhkan untuk membangun karakter kewirausahaan.

\section{HASIL DAN PEMBAHASAN}

Keberadaan kelompok remaja masjid di Kampung Kubur adalah suatu hal yang baik bagi remaja-remaja yang sedang menginjak dewasa. Pergaulan dengan remaja masjid mampu memberikan dampak yang positif bagi perkembangan remaja di Kampung Kubur. Kelompok remaja masjid sendiri baru mulai aktif kembali sejak tahun 2016 yang lalu, namun mampu memberikan dampak yang positif.

Keberadaan kelompok Remaja Masjid di Kampung Kubur berdampak sangat positif bagi remaja-remaja di Kampung Kubur. Sebab sebelum kelompok remaja masjid ini aktif dan memiliki berbagai kegiatan, menurut penuturan informan remaja-remaja lebih banyak menghabiskan waktu yang tidak bermanfaat diluar bersama teman-temannya dan tingkat penyalahgunaan narkoba sangat tinggi di kalangan remaja. Namun setelah kegiatan kelompok remaja masjid ini aktif, remajaremaja menjadi lebih banyak menghabiskan waktunya dengan hal-hal yang positif seperti belajar mengaji, melakukan pendalaman Alquran, membaca diperpustakan, belajar komputer, serta mengikuti kegiatan sosial seperti gotongroyong, dan juga kegiatan olahraga seperti sepak bola, basket, juga berenang sekali seminggu.

Kegiatan-kegiatan kelompok remaja masjid ini juga disambut baik oleh remaja dan juga masyarakat setempat, hal ini berarti kelompok remaja masjid memberikan dampak nyata bagi remaja maupun masyarakat setempat. Banyak orangtua yang kemudian ikut berpartisipsasi dengan mengikut sertakan anaknya dalam setiap kegiatan yang dilakukan remaja masjid. Karena mereka juga mengiginkan anakanaknya memiliki lingkungan sosial yang sehat dan dapat terjauhkan dalam pergaulan bebas dan tindakan-tindakan kriminal lainnya.

Permasalahan baru kemudian muncul seiring semakin hilangnya peredaran narkoba dari daerah tersebut. Banyak masyarakat yang kehilangan sumber mata pencahariannya. Kelompok remaja juga menjadi resah. Geliat ekonomi berkurang drastis.

Untuk itu guna mencegah kelompok remaja ini masuk kembali dalam peredaran negatif narkoba maka perlu untuk mengisi waktu mereka dengan hal-hal yang positif dan bermanfaat. Peluang usaha cuci motor dan mobil bisa jadi adalah salah satu usaha yang relatif tidak beresiko tinggi. Apalagi dengan jumlah sepeda motor atau mobil seperti ini makin bertambah, ditambah cuaca yang sering berubah dan budaya orang-orang di sekitar kita, maka membuka bisnis jasa cuci motor dan mobil merupakan alternatif yang cukup menjanjikan. Mungkin kita sering terlintas dengan jasa cuci motor atau mobil sepertinya sudah banyak tapi ingat jika kita ingin bersaing sama mereka tidak terlalu sulit yang penting adalah pelayanannya, yang harus dibedakan sehingga pelanggan kita benar-benar puas. 


\section{KESIMPULAN}

1. Kegiatan pengabdian berlangsung dengan baik dan memperoleh sambutan yang besar dari mitra.

2. Terjadi perubahan perilaku mitra menjadi senang untuk beraktivitas yang sifatnya positip.

\section{UCAPAN TERIMA KASIH}

Kegiatan pengabdian masyarakat yang telah dilaksanakan telah dapat diselesaikan dengan dan didapat hasil yang diharapkan dapat diadopsi oleh masyarakat. Dalam pelaksanaan kegiatan ini, tim peneliti banyak mendapat bantuan dari bebagai kalangan, sehingga kegiatan pengabdian ini dapat terlaksana. Sehubungan dengan hal tersebut, tim peneliti mengucapkan terima kasih kepada LPPM USU yang telah membiayai kegiatan ini.

\section{DAFTAR PUSTAKA}

BNN. 2015. Mengenal Penyalahgunaan Narkoba. Badan Narkotika Nasional. Jakarta.

Gunarsa, Singgih. 2012. Psikologi Praktis: Anak, Remaja dan Keluarga. Gunung Mulia. Jakarta.

Murtadho, D 2013. Penanganan dan Pemberdayaan Masyarakat Miskin Kota. PT. Sarana Perkasa. Jakarta.

Rianse, Usman, 2014. Membangun Usaha Mikro dan Kecil: Menciptakan Ruang Bagi Kesejahteraan Masyarakat Urban. Unhalu Press. Kendari.

Robert, Alberts R; J. Greene Gilbert. 2012. Buku Pintar Pekerja Sosial Jilid I. BPK Gunung Mulia. Jakarta.

Sarwono, Wirawan. 2012. Psikologi Remaja. Raja Grafindo Perkasa. Jakarta.

Soegandhi, 2015. Pembangunan Masyarakat Urban. PT Raja Grafindo Persada. Jakarta. 